\title{
Tradução e Mundo Árabe: Entrevista com Mamede Jarouche e Michel Sleiman
}

\author{
Marina Della Valle, Telma Franco Diniz e Gisele Wolkoff
}

Berço de uma arte narrativa e poética de indiscutível influência no processo de formação de várias literaturas e fonte de encantamento há séculos, "feixe de diferenças e contradições", palco de algumas das ditaduras mais sanguinárias do planeta, onde a censura pode ser "total, aterradora, onipresente, violenta, assassina”, o múltiplo Mundo Árabe é também fonte de inspiração e jardim de promessas para nossos caros entrevistados, os arabistas Mamede Jarouche e Michel Sleiman, ambos professores da USP e amigos dentro e fora da academia.

Vencedor do Prêmio Jabuti de Melhor Tradução de 2006 com o Livro das mil e uma noites - trabalho que se estendeu por uma década e resultou em quase duas mil páginas, lançadas pela Editora Globo em quatro volumes -, Mamede Jarouche diz preferir se ater à tradução de prosa, e se dedica atualmente, entre vários projetos, à tradução de uma obra do poeta hispano-árabe Ibn Hazm (9941064), O colar da pomba, tratado de caráter filosófico sobre o amor e os amantes, tido por Ortega y Gasset como "el libro más ilustre sobre el tema del amor en la civilización musulmana". Já Michel Sleiman - ele mesmo poeta, autor de Ínula Niúla (Ateliê Editorial, 2009), obra que talvez reflita o tempo em que o poeta viveu no Líbano durante a juventude - "procura a poesia onde quer que ela esteja”, e traduz desde suras do Alcorão e poesia árabe medieval a poetas contemporâneos, como Adonis, de quem publicou Poemas (Companhia das Letras, 2012), antologia que abarca quase 50 anos da produção poética do autor. Segundo ele, o leitor de poesia (em especial da poesia de Adonis) "deve abandonar o conforto da leitura passiva e ir ao encontro dos sentidos, produzindo-os"; e completa: "Ler ilumina". 
Embora tenham uma visão crítica do alcance de curto prazo da Primavera Árabe no que concerne o florescer das liberdades individuais - Michel, por exemplo, assinala que "a modernidade preconizada pela geração de Adonis esbarra em paradigmas antigos de difícil dissolução" que criam dificuldades para "O laicismo e a liberdade vingarem em meio a bandeiras e ideologias de toda ordem" -, ambos parecem confiar, dados lançados, na obra do longo acaso. Abrindo para os posicionamentos, considerações e esclarecimentos sobre "Tradução e Mundo Árabe" na entrevista dupla concedida a esta Cadernos 13 por esses dois renomados arabistas (na primeira parte, as respostas de Mamede; na segunda, as de Michel), fechamos com uma declaração de Mamede: "Apesar de tudo quanto se tem dito, apesar das coisas horrorosas que vemos, sobretudo na Síria, mas também no Iraque, da infâmia sucedida em Bahrein, da desesperança na Palestina, da Irmandade Muçulmana no Egito, da brutalidade sionista, ainda consigo ser otimista".

Sendo filho de imigrantes libaneses no Brasil, o árabe foi sua primeira lingua? Como era a comunicação dentro de casa? Você tem alguma lembrança específica de como se deu seu aprendizado do português e do árabe na infância?

Mamede - Sim, o árabe, ou, no meu caso específico, o dialeto libanês do Vale do Bekaa foi a minha primeira língua. Devido a injunções familiares, fui criado por meus avós paternos, que falavam mal o português, de modo que minha comunicação com eles era exclusivamente nesse dialeto. Lembro-me bem de que, quando comecei a ir para a escola, eu não sabia o nome de muitas coisas domésticas em português. Sempre me vem à memória, não sei por que cargas d'água, o caso da palavra "tomate", que eu somente conhecia como banadura. E também me lembro com clareza quando, na juventude, entre 81 e 82, fui estudar na Arábia Saudita, graças a uma bolsa fornecida pelo governo de lá. O meu maior choque foi descobrir que, absolutamente, eu não sabia árabe nenhum, que a minha linguagem doméstica não passava de um miserável dialeto caipira e, o que é pior, extremamente antiquado (eu o havia aprendido com os meus avós). Quando abria a boca, somente os libaneses me entendiam. E riam, riam muito. Eu ouvia coisas como "de onde você saiu?". Não é agradável. Aquilo me criou uma insuperável aversão ao meu dialeto familiar, cuja simples audição passou a me causar, até hoje, grande repugnância.

Como foi a experiência de estar no Egito no momento em que começaram os primeiros protestos da Primavera Árabe? Como vê o desenvolvimento da questão nos países árabes? 
Mamede - Foi uma grande experiência, fruto de uma coincidência e de um acaso maiores ainda. Normalmente, procuro ir para o Cairo nos começos de ano, por causa do recesso escolar no Brasil e também por causa da Feira Internacional do Livro que lá se realiza anualmente entre janeiro e fevereiro. E, em 2011, a revolução me surpreendeu, e considerei aquilo quase uma espécie de relâmpago num céu azul, para usar a imagem de Marx. Posteriormente, contudo, lendo com atenção relatos do que acontecia no mundo por assim dizer real, bem como textos de grandes analistas egípcios, dei-me conta da minha enorme ignorância: quem estivesse acompanhando com atenção a cena sócio-política no Egito não teria se surpreendido tanto. Fiquei triste, decepcionado mesmo, com a minha alienação em relação à contemporaneidade egípcia. Pareceu-me ridiculamente monstruoso, da minha parte, após tantos anos indo àquele país e após tanta certeza do meu amor por ele, não ter percebido o que ocorria, e que não era, de forma alguma, tão subterrâneo assim. Nem o fato de ser um estudioso de literatura clássica me livrou da culpa! Quanto ao desenvolvimento do processo revolucionário nos países árabes, ainda me parece muito cedo para emitir um juízo razoável. Todas as revoluções têm suas marchas e contramarchas. Por que o Mundo Árabe seria diferente? Apesar de tudo quanto se tem dito, apesar das coisas horrorosas que vemos, sobretudo na Síria, mas também no Iraque, da infâmia sucedida em Bahrein, da desesperança na Palestina, da Irmandade Muçulmana no Egito, da brutalidade sionista, ainda consigo ser otimista.

O poeta árabe Khalid Al-Maaly diz que os intelectuais árabes se apresentam ao ocidente com uma face mais aberta e cosmopolita, enquanto reservam uma face mais nacionalista e defensora dos valores árabes para "consumo interno" ("Two faces of Arab intellectuals"). Você concorda com ele? Como os intelectuais árabes têm reagido à Primavera Árabe?

Mamede - As coisas podem ser assim como meu amigo Khalid, extremamente crítico e acerbo, as define, mas podem igualmente ocorrer de maneira inversa, ou seja, existe o intelectual que se apresenta aberto e cosmopolita no Mundo Árabe mas, quando fala às academias do Ocidente e aos seus meios de comunição, faz questão de defender a tal "tradição". Não faltam exemplos. No Mundo Árabe, esse intelectual se sente esmagado e oprimido por uma porção de fatores tais como a tirania dos dirigentes, a estupidez e a obtusidade das autoridades religiosas, o conservadorismo em vários níveis, mas, quando fala às suas plateias

1 Disponível em: http://www.signandsight.com/features/993.html 
ocidentais, tenta justificar tudo isso. Parece esquizofrenia, mas é de caso pensado, permitindo-lhe extrair vantagens e distinções dos dois lados. Ademais, muitos intelectuais que estavam mamando nas tetas das ditaduras locais e tentando fazer acordos com elas hoje apoiam a Primavera Árabe. O que poderá sair disso? Desonestidade, oportunismo e cinismo fazem parte do DNA da maioria dos intelectuais no mundo todo.

Você viveu no Iraque antes da invasão dos Estados Unidos. Teve a oportunidade de voltar ao país após a guerra? Como foi o contato com as pessoas que conheceu lá?

Mamede - Trabalhei no Iraque em 85/86, quando o país estava em guerra com o Irã, uma guerra que, conforme se escreveu em algum lugar, "O mundo esqueceu", muito embora esse mesmo mundo - entenda-se aqui por "mundo", basicamente, os Estados Unidos - tenha sido quem a insuflou, atiçando a cobiça do criminoso oportunista Saddam Hussein para destruir a experiência revolucionária iraniana. Trabalhei lá por uma construtora brasileira que, segundo creio, faliu há alguns anos, a Mendes Jr. Foi uma experiência interessante do ponto de vista do conhecimento da língua, uma vez que tive de melhorar o meu árabe "na marra" trabalhando como tradutor e intérprete. E foi enriquecedor estar no Iraque, apesar de todas as restrições impostas pela guerra e pela ditadura de Saddam. Mas, por outro lado, foi muitíssimo desagradável ter trabalhado na tal construtora, convivendo com gente de baixíssimo ou nulo conhecimento humanístico, pessoas de uma abjeção intelectual tamanha que jamais me sairá da memória, sobretudo os brasileiros dos escalões mais altos da empresa. Havia exceções, claro, mas a grande maioria dos funcionários era constituída por aquele tipo de gente que faz você desejar a extinção da humanidade.

Como era a cena das artes e das letras no Iraque na época em que vivia lá? Em que nivel se dava a censura sobre as traducōes e sobre as outras artes? Que obras eram traduzidas para o árabe?

Mamede - A cena das artes e das letras era bastante empobrecida, não tenha dúvida. Primeiro, a guerra com o Irã, que condenava ao instrumentalismo mais chão qualquer manifestação artística. E, segundo, a própria natureza da sanguinária ditadura de Saddam, que reduziu o universo intelectual iraquiano a um grau quase zero. Praticamente não havia traduções de relevo, ao menos de que me lembre. E a censura era total, aterradora, onipresente, violenta, assassina. 
Em 1999 você traduそ̨iu o texto "Balança de traduções e dominação linguística", do professor de literatura egípcio Magdi Youssef, para a Cadernos de Literatura em Tradução 3. Nele o professor Youssef se mostra preocupado com a dominação do Mercado Mundial, administrado em lingua inglesa, que para ele representaria uma ameaca ao futuro da lingua árabe. Ele far um "apelo à tomada de consciência das alteridades linguisticas e culturais e à recusa da dominação". Como você vê essa questão? Em que sentido a lingua inglesa representa ou representou uma ameaça à língua árabe?

Mamede - Não saberia dizer em que medida o inglês ou qualquer outra língua ameaça o árabe. Isso está obviamente ligado à supremacia econômica e militar dos Estados Unidos e da Grã Bretanha. O inglês é a língua do império, mas não só. Acredito que o professor Magdi, bem como outros intelectuais, esteja se referindo aos usos e não à língua ou às línguas em si, já que não existe língua boa ou ruim. Pode-se ser imperialista em árabe, em francês, em tupi. Circunstancialmente, hoje a língua do império, e por consequência da administração do império, é em inglês. Isso dá uma prevalência à produção cultural e literária em inglês, claro, mas a língua inglesa não tem culpa nenhuma por isso! As elites árabes, por exemplo, preferem não raro utilizar o inglês ou o francês. Trata-se também da busca de padrões de distinção. Não é de bom tom, por lá, saber apenas árabe; o conhecimento de uma língua estrangeira é condição sine qua non de civilidade, diga-se assim. Essa questão linguística é bem controversa, sendo muito fácil resvalar para o conservadorismo quando se fala dela.

Naquele mesmo texto ${ }^{3}$ o professor Youssef se queixa da quase nula divulgação da literatura árabe no ocidente, e do pouco interesse da academia europeia no estudo da literatura árabe. Ele dá como exemplo o caso do escritor suiço Dürenmatt que em visita ao Cairo confessou nunca ter lido nada da literatura árabe a não ser o Livro das mil e uma noites. Desde então houve alguma mudança no cenário da literatura árabe no ocidente, em particular no Brasil? A que atribui isso?

Mamede - A literatura árabe, embora tenha enorme potencial, em todos os aspectos, não consta dos vários cânones elaborados em países do Ocidente. Isso tem raízes históricas bem complexas, pois é visível a importância dessa literatura no próprio processo de constituição de várias literaturas ocidentais. Essa

2 Disponível em: http://www.revistas.usp.br/clt/article/view/49320/53402

3 Veja nota acima. 
ignorância é sem dúvida nefasta, mas pode e deve ser combatida. Por princípio, sou contra posturas lamurientas, quaisquer que sejam os seus móveis. No Brasil, graças às peculiaridades locais, o desconhecimento da literatura árabe é maior, mas as possibilidades são melhores, dada a falta de preconceito anti-árabe nas camadas populares. Agora, claro, na esfera acadêmica esse desconhecimento e essa ausência têm causas evidentíssimas: boa parte da intelectualidade brasileira tinha o afã - provinciano e tolo, por sinal - de se afirmar como parte da "cultura ocidental", seja lá o que isso for, motivo pelo qual votou ao desprezo sistemático várias literaturas orientais, entre elas a árabe. Essa estupidez, alimentada pelo preconceito e pela mesquinharia, está felizmente fadada ao desaparecimento, em virtude da auspiciosa circunstância de que quase ninguém mais ouve os seus caducos defensores. E, sim, por incrível que pareça, a questão do engajamento com causas políticas justas no Oriente Médio, como a defesa dos palestinos ou das revoluções democráticas na região, acaba mais atrapalhando que ajudando, pois a absoluta maioria desses tais engajados não tem a menor empatia com a cultura e literatura árabes; pelo contrário, eles em geral desprezam tudo o que provém do Mundo Árabe; o engajamento é apenas um modo de manifestar sua militância política, ou sua oposição ao imperialismo, ou sua superioridade sobre aqueles pobres coitados (pois sabemos que sentir pena às vezes faz muito bem), ou, ainda, dar vazão a uma espécie de religiosidade reprimida. E tudo isso com uma boa dose de condescendência cínica.

Estilisticamente, quais os elementos do árabe você contemplou com mais atenção na traducão do Livro das mil e uma noites?

Mamede - Houve uma questão em especial que me deu trabalho e causou insônia: o ritmo. Em árabe, a narrativa desse livro é um moto-contínuo, não para nunca. Encontrar uma solução em português foi trabalho árduo. De cara se descartou tanto a justalinearidade como a paráfrase. Optei pela manutenção dos elementos semânticos dentro de estruturas sintáticas móveis, e troquei o aglomerado de orações coordenadas, isto é, ligadas pelas conjunções aditivas "wa" e "fa" (que correspondem ao nosso singelo "e") por longas frases subordinadas. Pareceu-me uma solução elegante e honesta. Em português a sucessão de frases coordenadas curtas causa a impressão de "soquinho", quase uma leitura gaga - ao menos é assim que as percebo. $\mathrm{O}$ árabe, ao contrário, justamente por ser uma língua com menores recursos para a subordinação, a sucessão de coordenadas soa como perfeitamente natural. Então, o meu trabalho consistiu, na primeira etapa, em traduzir sem os conectivos. Depois, na releitura, eu remontava inteira- 
mente as frases, de modo a criar muita subordinação. Frases longas e bem redigidas me deixam particularmente feliz ${ }^{4}$. Nada me repugna mais que a ditadura do texto jornalístico, as frases curtinhas, a proliferação de pontos finais. Uma coisa desenxabida, desanimadora, mas que está fazendo escola. Nem todo mundo é Camus para conseguir bons efeitos com isso.

O que é, em sintese sua, o Orientalismo? E o que significa o Orientalismo a partir do Brasil?

Mamede - Trata-se de um vocábulo de uso e conceituação controversos. Afastando-me inteiramente da concepção de Edward Said, que lhe dá uma carga pejorativa, digo que "orientalismo" é um genérico de estudiosos de coisas que, nos países da Europa e das Américas, pertencem ao Oriente. E os seus termos específicos são arabista (meu caso), sinólogo, hebraísta, assiriólogo, egiptólogo etc. etc. O estudo das civilizações do oriente no Brasil pode ser muito enriquecedor, já que o pesquisador brasileiro tem todas as condições, talvez mais do que os seus similares europeus ou norte-americanos, de realizar um trabalho mais despojado e despido de preconceitos.

Que poetas e escritores árabes estão merecendo ser traduzidos ao português? Alguma poeta ou escritora entre eles?

Mamede - São muitos, mas me desagrada fazer listas. Sim, claro, existem poetisas e escritoras entre tais merecedores. Por que seria diferente do resto do mundo?

Falar de poética em tradução em língua portuguesa no Brasil é...?

Mamede - Falar de um diálogo estético, muito necessário, cuja recepção e cujo receptáculo tendem à maleabilidade e à generosidade.

Há algum livro ou poema que você não tradůiria, e por quê??

4 Confira no Adendo, à página 263, trecho da primeira noite "das espantosas histórias das mil e uma noites". 
Mamede - Não traduziria nenhum livro de poesia, porque, muito simplesmente, não sou tradutor de poesia. Ademais, nem sequer sou estudioso de poesia árabe. Meu colega Michel Sleiman pode fazê-lo de maneira bem melhor e mais eficiente que eu.

\section{Com a palavra, Michel Sleiman.}

Além da traducão, você está envolvido em outras maneiras de divulgacão da cultura árabe no Brasil, tendo sido presidente do Instituto da Cultura Árabe até o ano passado. Percebeu algum aumento no interesse pela cultura árabe no Brasil, nos últimos anos?

Michel - Eu diria que nos últimos anos aumentou no Brasil a "curiosidade" por essa cultura. Em interesse eu não creio, pois ter interesse por algo significa ter disposição e força para ir fundo na informação, significa também a pessoa "abraçar a causa" do que verdadeiramente lhe interessa. Isso está longe do interesse que o brasileiro tem por outras culturas mais familiares. Mas, de todo modo, o aumento da curiosidade pela cultura árabe se deve a algumas variantes. Dada a carência de materiais de apoio para conhecer o mundo árabe, o trabalho dos poucos arabistas brasileiros em geral ganha visibilidade: produção de livros, artigos, debates, entrevistas que acabam nas livrarias e nos meios de divulgação. Se a produção dos arabistas é possivelmente a variante que mais alimenta os curiosos com relação a essa cultura, essa mesma atuação dos arabistas é posterior a um trabalho mais intenso e de fundo, que são as atividades menos perceptíveis do dia-a-dia nas salas de aulas, das orientações e coordenações de grupos de estudo e investigação, tudo permeado pelo trânsito entre os centros nacionais e internacionais de ensino e pesquisa, que mantêm o arabista conectado a outros focos de interesse além dos pessoais ou circundantes. Há que notar também a ação, por vezes coordenada, de algum centro cultural realmente atuante como tem sido o citado Instituto da Cultura Árabe fundado em 2004, que promove atividades mais abertas e interdisciplinares a um público menos especializado, levando ao conhecimento do brasileiro médio uma compreensão palatável e apurada das questões próprias do mundo árabe ou a ele relacionadas. Os centros culturais fazem isso, por exemplo, melhor que a grande mídia, a terceira das possíveis variantes. Os comunicadores da mídia infelizmente revelam ter pouca ou mesmo deficitária informação sobre o "árabe". Isso em parte reflete certa visão equivocada do jornalismo brasileiro, fisicamente mais distante dos cenários da cultura árabe (quando não é o caso deliberado de um trabalho a serviço da difamação). Mas, por outro lado, a desinformação revela uma apropriação rápida e mal digerida 
dos temas árabes. O maior desses erros é o de "etnicizar" essa cultura, não considerá-la naturalmente como um feixe de diferenças e contradições, próprias de todo sistema cultural, a exemplo do que aprendemos a reconhecer na cultura de franceses, italianos e espanhóis, ou outra tida por menos exótica. Será preciso dar um salto: tornar interesse a incipiente curiosidade com relação à cultura árabe. Acredito que a tradução seja central nesse processo. Ler ilumina. Tenho que apostar no trabalho dos arabistas, que, bem ou mal, não é um "produto do fato", no sentido de que não há hoje melhores arabistas porque houve o onze de setembro ou porque de tempos em tempos eclode uma guerra naquelas paragens.

Você se dedica a um campo bastante específico, poesia árabe-andaluza no período medieval. Como se deu esse interesse? Também tradur poesia contemporânea. Como se dá a escolha de autores e poemas?

Michel - Quando iniciei os estudos de pós-graduação eu era o que se pode chamar de personagem à procura de um autor no recém-ingressado palco de tradução. Tỉnha como propósito trabalhar com a linguagem poética em língua árabe, atividade para a qual o poeta Haroldo de Campos conclamava em Porto Alegre numa passagem sua pela UFRGS, em 1990, nas vésperas da minha colação de grau em Letras. Um ano depois entrava no Mestrado em Literatura Espanhola aqui na USP para estudar e traduzir a poesia andalusina, sob a orientação do Jorge Schwartz. O Jorginho (como era chamado pelo Haroldo de Campos) tinha orientado um ano antes outra dissertação atinente ao universo do Alandalus, que foi o estudo e a tradução por Zipora Rubinstein da maqama hebraica $A$ disputa entre o cálamo e a tesoura. A decisão por Ibn Quzman se justificou pelo alto grau de transgressão da poesia desse cordovês com relação ao cânone literário árabe de todos os tempos. Trata-se de uma poesia que explora um novo gênero poético, o rajal árabe-andalusino, escrito nesse dialeto que se deixa vazar pelo românico ibérico meridional, o berbere e o árabe clássico. A poesia de Ibn Quzman é um território de inventividade praticamente inexplorado pelos tradutores. A etapa desse trabalho, bem como a do posterior, no Doutorado, tiveram o acompanhamento de Haroldo de Campos, que praticamente balizou meus gostos e preferências no campo da tradução. Com ele, iniciei ainda outros dois projetos igualmente centrais nos meus estudos e ainda em curso: a tradução da poesia árabe contemporânea e a tradução do Alcorão. Procuro a poesia, onde quer que ela esteja.

Como seu processo de criação poética se relaciona com seu trabalho como tradutor de poesia? 
Michel - Como poeta e tradutor de poesia posso ser tomado por bissexto. Participei de três livros coletivos na época da Faculdade, nos anos 1980. Depois, só publiquei poemas na forma de livro no primeiro individual de 2010, o Ínula Niúla. Como tradutor, publiquei artigos e alguns livros de ensaio em torno de poemas que traduzi, mas efetivamente um livro integralmente de poemas traduzidos até agora só mesmo a antologia do poeta Adonis, que saiu no ano passado. Meu trabalho consiste mais em reescrever. Gosto do processo da refacção, da releitura. Na vida privada, revivi várias formas de presenças e ausências, entre um tempo e outro dentro e fora do Brasil. Em suma, seja para viver, para criar, para recriar sou um adepto da aprendizagem. Viver é uma arte que se aprende, não é mesmo? e fazer poemas, próprios ou traduzidos, é desfrutar dessa arte em outras instâncias, é retroalimentar a engrenagem desse aprendizado.

Alguns poemas de Adonis, que você traduそiu, soam ricos em aliterações como "Vož". "Desce/ entre os remos/ entre as rochas, encontra/ os errantes nas jarras/ das noivas, no murmúrio das ostras" - esse é um recurso poético típico na poesia árabe on é algo particular ao poeta? Que recursos poéticos são caros a Adonis? Algum poema lhe impôs maiores dificuldades na tradução?

Michel - A poesia de Adonis busca o ritmo, o som e o símile adequados para cada momento da poesia. Um poema é uma situação específica da criação. Não vejo nessa poesia fundamentos poéticos, prosódicos, métricos, dados a priori, e não encontro outro fundamento que não seja o do "por fazer-se". Nesse sentido, minha tradução aceitou o desafio de considerar uma linguagem própria para cada poema, uma linguagem consonante com os marcos de cada poema. Nesse que você cita, o som fabula o destapar de imagens dispostas nas linhas do poema como as camadas de uma boneca russa. Um "erre" se abre a outro "erre", imergindo as imagens nas sucessivas e cada vez mais internas camadas do mar, desde os remos na superfície, até às ostras mais a fundo. Não é, pois, a aliteração que se busca, mas a fita cinética que desenrola uns sons meio que ao azar, num lance de dados nada inocente (relembrando a máxima mallarmaica de que um lance de dados jamais abolirá o acaso). Com relação à dificuldade maior na tradução da poesia de Adonis, devo acusar a obra do poeta como um todo, porque ela exige do leitor, incluído o tradutor, uma postura ativa. Na definição de Adonis, poesia é linguagem difícil, em contraposição aos demais registros da linguagem.

5 Confira este poema no Adendo, à página 265 
Esse conceito ele colhe dos clássicos. O leitor deve abandonar o conforto da leitura passiva e ir ao encontro dos sentidos, produzindo-os, sendo por sua vez um leitor-poeta. Se ler ilumina, como eu disse antes, para o tradutor, aprender a ler é o caminho que ele deve perfazer até a iluminação.

Espigas e grãos de trigo são símbolos fortes na cultura árabe e ocorrem com certa frequência na poesia de Adonis, onde também notamos referências ao sino ("Mibyar éo sino dos errantes"s"; "carrego meus sinos na noite"), ao verde ("men amor é uma almenara verde"; "aspirou o fogo nos quartos verdes"," "Jesus desce a ele se inclinal verde como pérola") e ao sino e ao verde juntos ("o rosto dele sobre nós, como um sino verde"). O sino e o verde também fazem parte da simbologia árabe?

Michel - Faz parte da fábrica de metáforas, que é a poesia, a aproximação de cores e formas para o fabrico de uma ideia. É indiferente que ela seja dita em árabe ou chinês. $\mathrm{O}$ estranhamento dessas imagens que você cita vale para os leitores da poesia de Adonis em qualquer dos idiomas em que ela seja dada, desde o árabe. O "sino" remete a um poderoso campo de significações, o mesmo acredito se dá com o trigo e sua espiga, ou o verde e seus matizes. Note, porém, que esses elementos têm vigência apenas furtiva no poema. Surgem na sombra de outros elementos: sino/errantes/Mihyar, sinos/noite/carregador, / quartos/verdes/aspiração, verde/pérola/descida-revelação, sino/verde/rostocobertor. Esses elementos não jogam como símbolos, mas borram-se mutuamente. Ficam totalmente fora o étnico, o nacional, o linguístico, assim como a referência unívoca a algo, a um sentido ou um sistema de significações prédefinido, preexistente.

Os versos "Se não sei arrancar men pulso e atirá-lo sobre a mesal se não sei fazer da tristeza um tambor para o céu/ então é melhor eu dizer: minha vidal foi uma casa de fantasmas e um moinho de ventos", traduzidos por você, fazem parte do poema "O tempo" que abre o Livro do cerco, de 1985, em que Adonis tenta expressar sua dor diante da guerra civil do Libano. O nivel de doação para traduzir um poema como este, que projeta uma intensa carga de emoçôes do começo ao fim, é muito mais profundo? Como você, como tradutor, lida com isso?

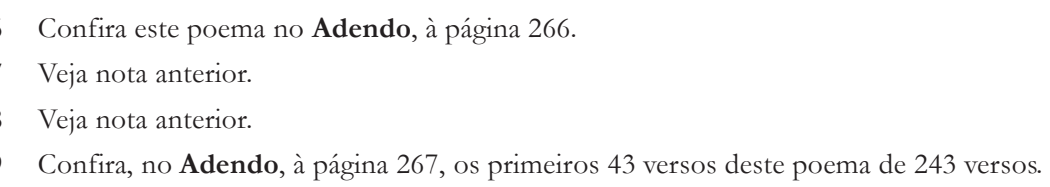


Michel - Traduzo com igual envolvimento um poema de um verso e outro de dez. E não distingo entre um mais carregado de emoção e outro aparentemente menos. Cada qual é como uma pilha que libera energia em intervalos e pontos distintos. Em mim, em você, em momentos diferentes de leitura. A percepção da emotividade me parece ser francamente pessoal. A minha é pela poesia como um todo. Há, contudo, a diferenciação do antes da tradução. Não traduzo poetas de que não gosto, não traduzo poemas por dinheiro, nem acho que esse tipo de tradução seja possível. Não se é um tradutor "profissional" de poemas, nos termos do mercado. Traduzo o que me parece relevante, vital e capaz de me transformar como pessoa. Encaro a tradução como uma maneira de fazer poemas; escrevê-los é a maneira que escolhi para viver.

O 'New Formalism', movimento poético de retomada de métrica e rima, vem ganbando forca nos Estados Unidos e na Inglaterra, onde sonetos e vilanelas convivem bem com o verso livre. No Brasil, Paulo Henriques Britto tem lançado mão de formas clássicas com excelentes resultados. Esse fenômeno tem similar na poesia árabe contemporânea?

Michel - Não. Por uma questão interna à história da literatura árabe, o momento divisório entre a prática do verso rimado/ritmado e a do verso livre é fluido e mesmo o seu início é tardio, data dos anos 1940. Coexistem nessa literatura diversas formas e "ethos" do poético, que se traduzem numa visão ora modernizadora, ora modernizante, ora classicista, ora classicizante. Pela simples razão de que o clássico árabe não é algo tão morto que precise ser ressurreto. Nem as balizas do moderno ancoram em solo suficientemente assentado para garantir um porto seguro às conquistas. A modernidade preconizada pela geração de Adonis tem esbarrado em paradigmas antigos de difícil dissolução, dentre cujas consequências está, a cada volta e meia, a dificuldade de o laicismo e a liberdade vingarem em meio a bandeiras e ideologias de toda ordem, que fazem o moderno soar como um dos maiores perigos que podem borrar o árabe e o islâmico de suas conquistas históricas e jogá-los num solo de modernidade que é todo lama, perdição e alienação aos olhos de revolucionários de outra estirpe: vide as ações após a revolução que priorizou os aiatolás, os regimes nacionalistas de Síria, Iraque, Líbia e Egito, entre outras reviravoltas. O clássico, que ao longo do século XX pôde ser sinônimo de antigo e ultrapassado, pôde também ser referência de unidade e reunificação de um mais amplo terreno do árabe. Daí que o impeditivo da morte do clássico seja a permanência de uma língua árabe padrão, comum em toda a extensão do mundo árabe, e que é uma versão atualizada e mais ou menos consensual do árabe clássico num meio em que vicejam falares e dialetos múlti- 
plos, com matizes étnicos e regionais que, na prática, moldam a realização desse mesmo árabe padrão e que é, no final das contas, o tipo de árabe mais frequente de que se vale a poesia moderna/contemporânea. Então não faz sentido o culto a tal "formalismo novo". De certo modo, o verso demorado das "qasidas" que contam as façanhas de Ulisses na árabe Iliadha não está tão longe da linha em prosa de outro arabizado Ulisses a que deu vida James Joyce... Ambos foram jogados pela tradução no meio-campo da literatura árabe... e debatem-se arranhando os limites do moderno.

Que poetas e escritores árabes estão merecendo ser traduzidos ao português? Alguma poeta ou escritora entre eles?

Michel - Ora, não temos praticamente nada em português. E não vejo nenhuma grande poeta mulher. Precisamos pensar numa antologia de poetas árabes contemporâneos, para cuja realização venho formando um grupo de tradutores estudantes de árabe. Além dos mundialmente reconhecidos Adonis e Mahmoud Darwich, prontamente citados pelos leitores de poesia, chamaria atenção para o poeta libanês Abbas Baidun, 67 anos, que vem publicando desde 1982. Tem uma poesia límpida, capaz de levar a leitura de seu tempo ao tempo mais real da poesia. E cito o também libanês Rachid Daif, o poeta que se voltou ao melhor romance. Nem bem nasciam os países árabes após as Grandes Guerras, e a Palestina foi tornada o lado escuro da lua no céu mais obscuro destes tempos. Por essa razão, acho válida em especial a publicação de uma antologia da poesia palestina, rosa das rosas, encabeçada pelo seu mais emblemático poeta, Darwich, a quem venho dedicando parte dos meus estudos.

\section{Falar de poética em tradução em língua portuguesa no Brasil é...?}

Michel - ...é falar de uma revisão e de uma mais ampla abertura da língua portuguesa e sua literatura brasileira. 